\title{
Prezentacje
}

\section{Modernizm i awangarda: pokrewieństwa i różnice ${ }^{1}$}

Mark Lipowiecki

TEKSTY DRUGIE 2018, NR 5, S. 195-211

DOI: $10.18318 /$ td.2018.5.12

Twierdzenie, że epoka modernizmu w literaturze rosyjskiej zakończyła się w 1917 roku, dawno zostało obalone we współczesnym literaturoznawstwie. Szkoła zagrzebskiego rusycysty Aleksandra Flakera i uczeni, którzy publikowali w latach 8o. XX wieku w holenderskim piśmie „Russian Literature” (głównie Igor Smirnow i Johanna Renate Döring²), by nazwać modernizm rozwijający się w latach 20. i 30. XX wieku, używali terminu ,historyczna awangarda”.W tym samym znaczeniu

1 Przekład z języka rosyjskiego na podstawie: М.Н. Липовецкий Модернизм и авангард: родство и различие, „Филологический класс" 2008 № 20, s. 24-31. Tekst oryginału został udostępniony na otwartej licencji Creative Commons Attribution (CC-BY): https://cyberleninka.ru/article/n/modernizm-i-avangard-rodstvoi-razlichie.

2 Zob. И.Р. Деринг-Смирнова, И.П. Смирнов Очерки по исторической типологии культуры: Реализм, постсимволизм (авангард), Institut für Slawistik, Salzburg 1982. Zob. też: И.П. Смирнов Мегаистория: К исторической типологии культуры, Аграф, Москва 2000, s. 11-196.

\section{Mark Lipowiecki}

(Leiderman) - profesor Uniwersytetu Kolorado (Boulder, USA), rosyjski i amerykański krytyk literacki, historyk literatury, szczególnie okresu sowieckiego i postsowieckiego, badacz postmodernizmu. Opublikował m.in.: Russian Postmodernist Fiction: Dialog with Chaos (1999), Charms of the Cynical Reason: The Trickster Trope in Soviet and Post-Soviet Culture (2011). 
stosowano termin „postsymbolizm”, który zyskał popularność w postsowieckim literaturoznawstwie ${ }^{3}$.

Rozwój terminologii epoki miał dla niej kolosalne znaczenie, ponieważ mimo istniejących tradycji ideologicznych pozwalał spojrzeć na kulturę sowiecką nie jak na zaprzeczenie i wypaczenie modernizmu srebrnego wieku, ale jak na kontynuację i transformację modernizmu. Badania w tym kierunku wyraźnie potwierdzały ciągłość między poszukiwaniami artystycznymi srebrnego wieku a twórczością autorów, którzy albo przeszli po rewolucji znaczną ewolucję wewnętrzną (Andriej Bieły, Anna Achmatowa, Marina Cwietajewa, Boris Pasternak, Osip Mandelsztam, Władimir Majakowski, Władysław Chodasiewicz, Gieorgij Iwanow, Jewgienij Zamiatin i inni), albo rozwinęli w pełni talent po 1917 roku (Isaak Babel, Jurij Olesza, Boris Pilniak, Michaił Bułhakow, Władimir Nabokow, Andriej Płatonow, Ilja Ilf i Jewgienij Pietrow, Daniił Charms i inni poeci grupy OBERIU, Nikołaj Erdman, Michaił Zoszczenko, Warłam Szałamow).

Równocześnie słabość tego podejścia wynika z faktu, że w dalszym ciągu dominowały w nim samookreślenia ugrupowań artystycznych i nurtów, które wykształciły się głównie w latach 1900-1910, a później na początku lat 20. XX wieku. Poza tym wyobrażenia o „historycznej awangardzie” czy "postsymbolizmie" zacierają różnice między modernistyczną a awangardową estetyką (trudności przysparza sama terminologia - w zachodnim literaturoznawstwie awangardę często rozumie się jako synonim modernizmu) ${ }^{4}$. Tymczasem polityczne zaangażowanie awangardy i jej bezpośredni związek $\mathrm{z}$ ideologią rewolucyjną wymagają bardziej rygorystycznego podejścia do granic między awangardowymi a modernistycznymi poszukiwaniami w kulturze lat 20. i 30. XX wieku przy zdroworozsądkowym rozumieniu interakcji istniejących między tymi tendencjami, a także tego, że zarówno moderniści, jak i awangardziści w równym stopniu okazali się ofiarami socrealistycznego monopolu.

3 Zob. Постсимволизм как явление культуры: Материалы международной конференции, ред. И.А. Есаулов, РГГУ, Москва 1995; Постсимволизм как явление культуры: Материалы международной конференции, ред. С.Н. Бройтман, И.А. Есаулов, РГГУ, Москва 2003; В.И. Тюпа Постсимволизм: Теоретические очерки русской поэзии XX века, Научно-внедренческая фирма «Сенсоры, Модули, Системы», Самара 1998; Н.В. Дзуцева Время заветов: Проблемы поэтики и эстетики постсимволизма, Ивановский госуниверситет, Иваново 1999.

4 Takie podejście zostało zaprezentowane głównie w pracach T. Adorno, G. Lukácsa, a później P. Bergera. 
Należy określić nowa jakość, która uformowała się w późnym rosyjskim modernizmie ,ponad barierami”, ponad samookreśleniami się ugrupowań i twórczymi kontaktami, zarówno w tych wersjach, które powstawały w obrębie kultury sowieckiej, jak i w undergroundzie i na emigracji.

\section{I}

Już od lat 9o. XIX wieku kluczową cechą modernistycznej świadomości było wysunięcie się na pierwszy plan subiektywnego postrzegania świata, tworzącego szczególnego rodzaju estetyczną ,teorię względności”. Autor-modernista, poddając kreowany obraz świata wszechstronnej problematyzacji, nieustannie podważając każdy dogmat i relatywizując każdy system wierzeń, zawsze ma świadomość czasowej i hipotetycznej istoty swoich poglądów i wyobrażeń. Zdaniem badaczy „w modernizmie hipoteza intelektualna zastępuje zarówno materialistyczny i psychologiczny determinizm realizmu, jak i postulat symbolizmu o odpowiedniości między światem zjawisk a wyższą realnością Piękna i Prawdy”. „Odrzucając symbolistyczną metafizykę i realistyczne próby integracji jednostki z materialnym otoczeniem, modernizm za punkt wyjścia bierze indywidualna świadomość. W centrum uniwersum semantycznego modernizmu znajduje się indywidualna świadomość, dążąca do osiągnięcia niezależności od każdego oddziaływania płynącego z zewnątrz po to, aby postrzegać świat z niezależnej pozycji”. „Indywidualna świadomość znajduje się na szczycie modernistycznej hierarchii semantycznej. Pisarz nie jest już pośrednikiem między światami, jak w symbolizmie; jego miejsce jest w samym centrum wytwarzanego przez niego świata"7.

Z tymi własnościami modernistycznego dyskursu bezpośrednio związana jest mitologia autorskiego , ja”, czy właściwie tworzenie indywidualnego autorskiego mitu, nadającego epistemologicznie niepewnej autorskiej hipotezie cechy paradoksalnego uniwersalizmu. Tak jest z autorskimi mitologiami Błoka, Gumilowa, Achmatowej, Jesienina, Charmsa, Majakowskiego, Klujewa, Brodskiego - oni dosyć często (choć nie zawsze) kreują własną osobę na wzór mitologicznych obrazów (Rycerza, Pierrota i Arlekina u Błoka, Chrystusa u Majakowskiego, Kasandry u Achmatowej) i artystyczne, podporządkowane

\footnotetext{
5 D. Fokkema, E. Ibsch Modernist Conjectures: A Mainstream in European Literature. 1919-1940, St. Martin Press, New York 1988, s. 41.

6 Tamże, s. 43.

7 Tamże, s. 44.
} 
logice twórczości zachowanie autora (tzw. „życiotworzenie”, wykraczające daleko poza granice symbolizmu, gdzie ta kategoria się pojawiła). Nieprzypadkowo to właśnie praktyka artystyczna modernizmu potrzebowała wprowadzenia pojęcia „bohater liryczny”. Przypomnimy, że autor tego terminu - Jurij Tynianow - bynajmniej nie miał na myśli obrazu osobowości autora w tekście literackim, lecz obraz osobowości autora, który przesłania osobowość i dominuje nad percepcją czytelnika, czyli inaczej mówiąc - autorskimit:

Błoka mało kto znał. Jako człowiek pozostał on zagadką dla szerokiego kręgu literackiego Piotrogrodu, nie mówiąc już o całej Rosji.

A przecież w całej Rosji ludzie znaja Błoka jako człowieka, ufają wyrazistości jego wizerunku i jeśli zdarzy się komuś choć raz zobaczyć jego portret, ten już czuje, że zna go doskonale.

Skąd bierze się to przeświadczenie?

Możliwe, iż tu właśnie tkwi klucz do poezji Błoka; i jeśli w chwili obecnej nie sposób znaleźć odpowiedzi na owo pytanie, można je przynajmniej sprecyzować.

Błok - to największy temat liryczny Błoka. Temat ów przyciąga, fascynuje, jak temat powieści nowego gatunku, gatunku, który się jeszcze nie narodził (lub nie zadomowił w naszej świadomości). O tym właśnie bohaterze lirycznym mówi się teraz. ${ }^{8}$

Jednak mitologizacja osobowości autora jest jedynie środkiem do potwierdzenia absolutu subiektywności, leżącego u podstaw modernistycznej artystyczności. Właśnie ta zasada określiła logikę rozwoju języka artystycznego, nieustannie i radykalnie się odnawiającego, zrywającego z dominującymi tradycjami (tym, co traktowane jest jako „wspólne”, kolektywne), ukierunkowanego na nieprzerwane „udziwnienie”, wyrażającego właśnie skrajnie indywidualne spojrzenie na świat.

Świadomość tragicznej ograniczoności mitu wynikającej z możliwości poznawczych jego twórcy i ram stworzonego przezeń tekstu literackiego równocześnie określa paradoksalność modernistycznego automitologizmu. Relatywność subiektywnego mitu, tworzonego przez modernizm, najdokładniej przejawia się przynajmniej w trzech najważniejszych aspektach modernistycznej poetyki: (1) intertekstualności (i obrazie kultury, który jest

8 J. Tynianow Błok, przeł. E. Korpała-Kirszak, w: Fakt literacki, wyb. E. Korpała-Kirszak, PIW, Warszawa 1978 , s. 88. 
tworzony z jej pomocą); (2) artystycznym zogniskowaniu na sferze nieświadomości zarówno w indywidualnym, jak i społecznym życiu; (3) stworzeniu indywidualnych - i relatywnych - modeli sacrum.

(1) Pisarz-modernista musi koniecznie stosować liczne ukryte i jawne cytaty, odwołania i aluzje do klasycznej i współczesnej literatury. Mandelsztam i Achmatowa są jawnie obnażeni ,intertekstualnie”, mniej jawne, ale nie mniej znaczące interteksty przenikają prozę Babla, Zoszczenki, Oleszy, Nabokowa i wielu innych ${ }^{9}$. Powiązania intertekstualne po pierwsze, akcentują tworzone przez artystę „udziwnienie" istniejącego kulturowego materiału, a po drugie, układają się w czysto indywidualny (nierzadko swój dla każdego utworu) obraz kultury, przekształconej z zewnętrznego kontekstu w pejzaż wewnętrznego świata modernisty. Przy tym oczywiście zawartość tego obrazu kultury, wchodzące w niego wartości kulturowe czy pozostające poza jego granicami, a także po prostu wymiar tego obrazu przeobrażają się w najbardziej przekonującą materializację autorskiego mitu. W tym sensie istnieje ogromna, odczuwalna przepaść między otwartymi i wieloznacznymi obrazami kultury, które powstają w twórczości „,następców srebrnego wieku”, a obrazem kultury, powiedzmy, w poezji „komsomolskich” poetów, dla których najważniejszym wydarzeniem w historii świata był i pozostawał rok 1917.

Na tej zasadzie Konstantin Waginow w swojej powieści Pieśń kozła [Козлиная песнь] (1927-1928) przedstawia degradację i zagładę lepszych: subtelnych i wytwornych petersburskich inteligentów, ludzi, którzy mają ,,wykształcenie i zainteresowania filologiczne ${ }^{10}$ - można też powiedzieć bez cienia przesady - ostatnich strażników ducha umierającej epoki kulturowej. Prawdziwym tragizmem przepełniona jest scena, w której Ciepciołkin, podnosząc kielich z epoki odrodzenia, pije za zagładę XV wieku. A i Pietrograd połowy lat 20. (aż nadto tłuste czasy NEP-u!), wyłaniający się ze stronic Pieśni kozła [Козлиная песнь], wygląda u Waginowa jak miasto, które przeżyło (albo przeżywa) koniec świata.

Akcent końca świata brzmi wyraźnie w scenie śmierci żony Ciepciołkina - Marii Pietrowny Dałmatow, scenie muzyki, marzeń: „,wydawało mu się [Ciepciołkinowi], że za jej sprawą świat przeistacza się w precyzyjną i harmonijną jedność"11.

9 Analiza tekstów rosyjskich modernistów pod względem intertekstualności zob. w: А.К. Жолковский Блуждающие сны и другие работы, Наука, Москва 1994.

10 K. Waginow Pieśń kozła, przeł. A. Pomorski, „Literatura na Świecie” 2013 nr 11/12, s. 7.

11 Tamże, s. 7. 
Jednak jeśli mamy do czynienia z apokalipsą, to szczególnego rodzaju - szydercza. Nie bez przyczyny tragiczne zabarwienie sceny śmierci Marii Pietrowny przeplatają autorskie posłowia (w wydaniu czasopismowym). Dowiadujemy się z nich czegoś nowego o głównym bohaterze powieści erudycie i poliglocie, ostatnim rycerzu odrodzenia - Ciepciołkinie:

Autor cały czas próbował uratować Ciepciołkina, ale uratować Ciepciołkina mu się nie udało. Wcale nie biednie żył po wyrzeczeniu się swoich marzeń Ciepciołkin. Wcale nie mało osiągnął w życiu, nigdy nie ogarniało go zwątpienie w samego siebie [...]. Wcale nie biednym pracownikiem w klubach został Ciepciołkin, a wybitnym, ale głupim gryzipiórkiem. I żadnym ogródeczkiem na podwórku nie zajmował się Ciepciołkin, wprost przeciwnie, krzyczał na biednych urzędników i był strasznie wymowny i dumny z osiągniętej pozycji. ${ }^{2}$

Degradacja bohatera i przeobrażenie ostatniego rycerza odrodzenia w najpospolitszego marksistowskiego dogmatyka jak na ironię wynika z kultu kultury - z dążenia do wyprowadzenia z kultury stałej, danej na wieki „hierarchii znaczeń". Właśnie taki tytuł nosi najważniejsza książka Ciepciołkina. Ale może i dlatego Ciepciołkinowi nie było dane dokończyć tego utworu, że kultura sprzeciwia się takiej przemocy? Ciepciołkin w sposób religijny (chrześcijański, a nie pogański) absolutyzuje kulturę, sprowadzając ją wyłącznie do wysokich znaczeń:

Ciepciołkin czytał foliały, które niegdyś tak bardzo poruszały ludzkość. Mój Boże, przecież książki zawsze poruszają ludzkość. I czymże są lepsze nowe książki od starych? One też kiedyś staną się stare. Z nich też kiedyś będą kpić. A w starych książkach jest słońce i subtelność duszy, i śmieszne dziwactwa, i potworna rozwiązłość; wszystko jest w starych książkach. Ciepciotkin dostrzegat w nich jednak tylko stońce i elegancję duszy, rozwiazłość i ignorancja w jego odbiorze jakoś ciemniaty i stawaty się zjawiskiem przypadkowym, nieodtaczna czasteczka wszechświata. W jego odbiorze wszechświat miat tylko jedno oblicze, a Odrodzenie w jego odbiorze jaśniało zawsze jedna strona. Odrodzenie byto w jego odbiorze wytacznie jasne [kursywa moja - M.L.]. ${ }^{13}$ проект, Санкт-Петерсбург 1999, s. 466-467. 
Absolutyzacja kultury ułatwia również Ciepciołkinowi przejście na pozycję marksistowskiej albo jakiejkolwiek innej ortodoksji: jego uwielbienie kultury od samego początku opierało się na represji wobec wszystkiego, co nie wpisuje się w idealizowany obraz wieczności, duchowości i piękna. Zawiera się to w klasycznym paradygmacie kultury: „Wspaniałe być powinno, co jest cudne"14 - i Ciepciołkin z całym ogromem swojej erudycji tylko częstokroć wzmacnia ten, nie tak oczywisty do czasu, dogmatyzm.

Ale nie tylko wewnętrzna problematyczność i konfliktowość modernistycznego obrazu kultury odpowiada za estetyczny relatywizm poetyki modernistycznej. Niemałą rolę odgrywa także to, że hipertrofia indywidualności (samosti), własnego , ja", stawia modernistów przed tragicznie nierozwiązywalnym problemem Drugiego - w rosyjskiej tradycji kulturowej niezmiennie związanym z obrazem naroda i/lub władzy, państwa ${ }^{15}$. Nieprzejednana wojna z Drugim zakłada wiele rezultatów; wśród skrajnych: albo uznanie Drugiego za swojego sobowtóra (np. droga Płatonowa), albo masochistyczne zniszczenie ,ja” w imię ,narodnoj prawdy" (droga modernistów i awangardzistów, którzy „przekuwali się"w socrealistów: Władimira Majakowskiego, Leonida Leonowa, Borysa Pilniaka, Borysa Eawrieniewa i innych), albo odwrotnie, droga pełnej izolacji od jakiejkolwiek komunikacji z Drugim, heroicznego lub stoickiego samozachowania subiektywnej pozycji za wszelką cenę (pozycja wielu undergroundowych modernistów i awangardzistów lat 60. i 80.).

Jedną z najbardziej efektywnych zasad, wypracowanych przez modernizm w odpowiedzi na problem Drugiego, jest poetyka polifonizmu, a w szczególności powieści polifonicznej, wypracowana przez Bachtina na przykładzie Dostojewskiego. Ten teoretyczny model wyrażał poszukiwania estetyczne sztuki modernistycznej i znalazł artystyczne uosobienie przede wszystkim w twórczości emigracyjnych i undergroundowych pisarzy lat 6o. i 70. - w Loliсіе [Лолита] і Bladym ogniu [Бледное пламя] Władimira Nabokowa, w utworach Abrama Terca (Andrzeja Siniawskiego), Wieniedikta Jerofiejewa, Saszy Sokołowa. Chociaż w latach 70. przenika on i do „dozwolonego” piśmiennictwa, najbardziej widoczny jest np. w późnej twórczości Jurija Trifonowa.

(2) Subiektywna i zsubiektywizowana optyka modernizmu jest najbardziej przysposobiona do wyjawienia nieświadomych procesów, określających

14 A. Puszkin 19 października, przeł. L. Lewin, w: A. Puszkin Wybór wierszy, Ossolineum, Wrocław 1982, s. 202.

15 Zob. A.М. Эткинд Фуко и тезис внутренней колонизации, „Новое литературное обозрение" 2001 № 49, s. 51-73. 
w modernistycznym paradygmacie zarówno życie jednostki, jak i transformacje społeczeństwa i kultury. Zwrot ku nieświadomości wyraża ważki aspekt sztuki modernistycznej i kultury w ogóle, a mianowicie krytykę nowoczesności (modernosti), opartej (co najmniej od czasów oświecenia) na kulcie racjonalności, na wierze w to, że postęp jest możliwy dzięki racjonalnej kontroli nad społeczeństwem (tym, co znany filozof i socjolog Zygmunt Bauman nazywa „kulturą ogrodniczą"). Pod koniec XIX wieku pokazano wiele sprzeczności wewnątrz nowoczesnej (modernoj) cywilizacji, a przede wszystkim sprzeczność między racjonalnymi wyobrażeniami o postępie społecznym a nieświadomą i irracjonalną wolnością osobistą. W Rosji tę sprzeczność po raz pierwszy przedstawiono na przykładzie „człowieka z podziemia” Dostojewskiego, a na Zachodzie ten kulturowy zwrot wiąże się przede wszystkim z efektem wytworzonym przez filozofię Nietzschego i teorie Freuda. Obydwaj ci myśliciele wywarli silny wpływ na kulturę rosyjską ${ }^{16}$. Jak pisał Aleksandr Benua: „Idee Nietzschego osiągnęły wtedy [na początku XX wieku] wyraźnie aktualny charakter (podobny charakter osiągnęły idee Freuda)"17. Nietzsche i Freud wywarli silny wpływ na światową i rosyjską kulturę XX wieku właśnie dlatego, że zaproponowali mniej lub bardziej zracjonalizowany dyskurs, pozwalający operować nieświadomością jako centralnym znaczonym (signifiè) modernistycznej kultury w ogóle. Warto podkreślić, że sprzeczność między (quasi) racjonalnymi projektami społecznej rywalizacji a nieświadomą wolnością osobistą szczególnie wyostrza się właśnie w kulturze rosyjskiej okresu sowieckiego, kiedy "plan rozwoju” nabiera cech politycznego i ideologicznego monopolu, potwierdzającego swoją władzę przemocą.

Dążenie do znalezienia języka nieświadomości lub bezpośredniego zwracania się do nieświadomości czytelnika/widza wpłynęło nie tylko na najważniejsze tematy literatury modernistycznej, łączącej zainteresowanie seksualnością z mistyką i okultyzmem, zafascynowanej transgresjami różnego rodzaju i skali (od indywidualnej przemocy do masowych eksplozji, wojen, rewolucji), swobodnie wykorzystującej motywy fantastyczne. „Logika nieświadomości” podyktowała także przywiązanie sztuki modernistycznej do takich tropów jak ironia, oksymoron, katachreza, absurd,

Zob. Nietzsche in Russia, ed. by B. Rosenthal, Princeton University Press, Princeton 1986; D. Kujundzic The Returns of History: Russian Nietzscheans After Modernity, SUNY Press, New York 1977; А.М. Эткинд Эрос невозможного: История психоанализа в России, Гнозис-Прогресс-Комплексб, Москва 1994. 
groteska (każdy z tych tropów, lub ich połączenia, wysuwa się na pierwszy plan w różnych modernistycznych nurtach), kolosalne znaczenie prozodii i neorytualnej performatywności (szczególnie ważnej dla awangardowego skrzydła modernizmu).

Oto jak powieść Jewgienija Zamiatina $\mathrm{My}[\mathrm{Mbl}]$ (1921) przedstawia najważniejszą dla europejskiego modernizmu fabułę: bunt nieświadomości przeciwko wszelkiej świadomości, racjonalności i systematyczności. Ten proces przedstawiony jest w powieści nie tylko poprzez ewolucję psychologiczną D-503, ale i całą logikę przejścia Jedynego Państwa od stanu mechanicznego uporządkowania do społecznego wybuchu, bezsensownego i bezwzględnego: „bo w zachodnich dzielnicach - ciagle jeszcze chaos, ryk, trupy, bestie i niestety - znaczna ilość numerów, które zdradziły rozum"18.

Rozumienie nieświadomości jako mechanizmu napędowego nie tylko psychologicznych, ale i społecznych procesów właściwie czyni powieść $M y$ $[\mathrm{Mbl}]$ paradygmatyczną i modernistyczną, łączącą poprzez kategorię nieświadomości i irracjonalności osobliwie rozumianą dionizyjskość rosyjskich symbolistów ${ }^{19} \mathrm{z}$ nadchodzącym absurdyzmem (OBERIU) i neomitologizmem (Bułhakow, Płatonow). Zamiatin nie tylko bez wahania utożsamia wolność indywidualną z nieświadomością, ale niedwuznacznie wiąże centrum, źródło i impulsy nieświadomości z seksualnością - w przypadku D tę rolę odgrywa jego uzależnienie seksualne od I-330. W odróżnieniu od spokojnych i przemyślanych kontaktów z $\mathrm{O}$, regulowanych dotyczącym życia intymnego prawem, romans D z I rozwija się zgodnie z irracjonalną logiką żądzy i opisywany jest przez samego D jako choroba, szaleństwo, utrata świadomości. Równocześnie, jak zauważa Thomas Riley Edwards, ,,seksualność w My [Mbl] jest identyfikowana $\mathrm{z}$ fundamentalnym tematem Zamiatina - wolnością"20.

(3) Krytykując oświeceniowy paradygmat kultury nowoczesności (modernosti) - którą po rosyjsku z wielką niedokładnością określa się jako Nowoje wriemia (czasy nowożytne) - opartej na ideologii uniwersalnego rozumu i postępu, i wcielając ten kryzys do tradycyjnych, a przede wszystkim religijnych podstaw kultury, w którego sprawie jako pierwszy zabrał głos Nietzsche,

18 E. Zamiatin My, przeł. A. Pomorski, Wydawnictwa ALFA, Warszawa 1989, s. 181.

Związek powieści Zamiatina z dionizyjskim i orfickim kultami i ich literacko-filozoficzna interpretacja zostały przeanalizowane przez S. Piskunową. Zob. С. Пискунова Мы Е. Замятина: Месистофрель и Андрогин..., „Вопросы литературы” 2004 № 6, s. 99-114.

20 T.R.N. Edwards Three Russian Writers and the Irrational: Zamyatin, Pil'nyak, and Bulgakow, Cambridge University Press, Cambridge 1982, s. 47. 
moderniści rozumieją sztukę jako sposób na szukanie czy właściwie stworzenie sacrum lub jako mechanizm albo magiczny przyrząd do wynalezienia wieczności. „Śmierć Boga, jak się okazuje, odkryła nową erę poszukiwań religijnych - poszukiwań, które często były mierzone i oceniane nie według wyników, a raczej według oznak czystej intensywności, poszukiwań, które w ostatecznym rozrachunku były celem samym w sobie" - konstatuje amerykański teoretyk Matei Călinescu²1.

Rosja, która nie znała Reformacji, przeżywała kryzys religijny końca XIX i początku XX wieku znacznie silniej niż Europa czy Ameryka. Z tej przyczyny orientacja na stworzenie nowych (albo odrodzenie starych i zapomnianych) sakralnych znaczeń determinuje całą historię rosyjskiego modernizmu i awangardy: od symbolistycznej teurgii do Czarnego kwadratu Malewicza, od bogoburstwa Majakowskiego do Bułhakowowskiego przedefiniowania chrześcijaństwa z Diabłem w charakterze proroka, od Mandelsztamowskiej sakralizacji kultury - z katastrofą jako jej sensotwórczym centrum (niezwykle wymowna jest jego powieść Znaczek Egipski [Эгипетская марка], 1927) do Charmsowskiej estetycznej filozofii „nic". I rzecz znamienna - próby stworzenia subiektywnego i indywidualnego sacrum dość często prowadzą do mitologizacji obrazu artysty (nierzadko autobiograficznego), który występuje w roli współczesnego maga albo kapłana, wychodzącego poza granice społecznych i kulturowych norm czasu, przestrzeni, historii, a przy tym własnego losu. To wyjście poza granice jest najważniejszą cechą modernistycznego sacrum. Dlatego modernistyczny autor nie może być „od świata wyzwolony"22 (Mandelsztam), nawet jeśli jego strategia wiedzie w otchłań „niemiejącego czasu” („Musiałem ujść głęboko w czas, co z wolna niemiał”23). Dlatego nie ma nic bardziej charakterystycznego dla modernistycznego rozumienia wyższych - zawsze subiektywnych i zawsze marginalizowanych - wartości niż wykrzyknienie Mariny Cwietajewej:

Za miastem! Rozumiesz ty?

Poza: przekroczywszy granicę!

21 M. Calinescu Five Faces of Modernity: Modernism, Avant-Garde, Decadence, Kitsch, Postmodernism, Duke University Press, Durham 1987, s. 62.

O. Mandelsztam Jak kocham mroźne oddychania, przeł. M. Leśniewska, w: tegoż Poezje, Wydawnictwo Literackie, Kraków 1983, s. 491.

23 O. Mandelsztam Tak jak męczennik światłocienia - Rembrandt, przeł. S. Barańczak, w: tegoż Poezje, s. 509. 
Życie to miejsce, gdzie nie można żyć:

To ży - dowskie dzielnice...

Poemat końca $[\text { Поэма конияа }]^{24}$

Z poszukiwaniem indywidualnych i ambiwalentnych symboli sacrum wiąże się intensywny zwrot modernistów i awangardzistów ku archaicznym, a zwłaszcza marginalnym, zdecentralizowanym symbolom i formom sacrum - na ogół nie tylko jeszcze raz odkrytym, ale i na nowo stworzonym w modernistycznej kulturze. Jako znakomita ilustracja takiej „quasi-archaizacji” może służyć rytualno-mitologiczny zespół karnawałowych motywów - w teorii odkryty przez Bachtina, a w praktyce zrealizowany w wielu modernistycznych tekstach, napisanych na długo przed publikacją prac uczonego ${ }^{25}$.

Jednak należy podkreślić, że w odróżnieniu od innych porządków estetycznych (np. socrealizmu) w modernistycznym paradygmacie stworzone sacrum zawsze zachowuje relatywny charakter: albo jest zupetnie ambiwalentne, albo jawnie subiektywne, albo sam proces jego tworzenia przejawia się w konstrukcji tekstu, albo ma ono lekki i ironiczny charakter, wykluczajacy jednoznaczna, a już tym bardziej dogmatyczna interpretację itp. W planie konstrukcyjnym modernistyczny mit świadomie lub nieświadomie podważa zestawienie binarnych opozycji z uprzywilejowana pozycja jednej ze stron (typowe zarówno dla tradycyjnej kultury, jak i socrealizmu) modernizm zawsze dąży do tego, aby przeobrazić mit w wieloznaczne i niepoddające się dogmatyzacji zapytywanie o, znaczone (signifie) transcendentalne ${ }^{26}$.

W tym sensie dla modernistycznej sakralności nader znaczące jest częste połączenie mitotwórczości i metapoetyki: kiedy stworzeniu mitu towarzyszy obnażenie procesu stworzenia tekstu, realizującego ten mit. Mamy przed sobą nie tylko „obnażenie chwytu”, według terminologii Wiktora Szkłowskiego. Ważne jest i to, że mit, tzn. to, co według słów Tomasza Manna wyraża „pierwotnie dany wzór", powstaje w dosłownym sensie na oczach czytelnika nie w rezultacie profetycznego aktu, lecz w rezultacie przetransportowania, przeniesienia w wymiar mitologiczny zupełnie konkretnych i drobiazgowych

24 M. Cwietajewa Poemat końca, przeł. S. Pollak, w: tejże Poezje, oprac. i wstęp S. Pollak, PIW, Warszawa 1968, s. 221-222.

Niezwykle znamienne są takie utwory lat 20. jak Ulisses J. Joyce'a, Przygody dobrego wojaka Szwejka podczas wojny światowej (1921) J. Haška, a w literaturze rosyjskiej Niezwykłe przygody Julio Jurenito i jego uczniów (Хулио Хуренито, 1921) I. Erenburga, Psie serce (Собачье сердие, 1925) M. Bułhakowa, Opowiadania odesskie (Одесские рассказы, 1924-1926) I. Babla. 
warunków życia artysty. Dobrze ilustrują to przykłady z dylogii Waginowa Pieśń kozła [Козлина песнь] і Trudyi dni Swistonowa [Труды и дни СвистоноBa], praktycznie wszystkich powieści Nabokowa, począwszy od Obrony Łużyna [Защита Лужина], na Lolicie [Лолита] і Bladym оgniи [Бледное пламя] kończąc, ale szczególnie wymowne są oczywiście w Mistrzui Małgorzacie [Maстер и Маргарита] i Doktorze Żywago [Доктор Живаго]. Co jednak ciekawe, w rosyjskiej mitologicznej metaprozie (tzn. literaturze opisującej proces własnego tworzenia, ,pisanie o pisaniu”) rozwijają się dwie przeciwstawne tendencje - jedna próbuje ukryć relatywny charakter modernistycznego sacrum, druga przeciwnie - obnażyć go.

W Mistrzu i Małgorzacie [Macmep u Mapzapuma] i Doktorze Żywago [Доктор Живаго] akcent został położony na powtarzalność motywów, łączących różne poziomy narracji. Właśnie rytmiczne współbrzmienia między „dzisiejszymi" a mitologicznymi (legendarnymi) planami są interpretowane przez autorów jako odzwierciedlenie sakralnego centrum, realizowane z kolei w neomitologicznych obrazach (paralele między Jeszuą i Mistrzem; przemiana Jurija Żywago we współczesnego Chrystusa u Pasternaka). Jednak „powtarzalność” w tych powieściach jest wyraźnie wymuszona, ,rytm współbrzmienia", mimo usilnych starań Bułhakowa i Pasternaka, nie może wygładzić rozbieżności między mitologicznym a współczesnym bohaterem. Właśnie tym tłumaczy się liczne sprzeczności wymienionych powieści, wzbudzające niejednokrotnie burzliwe dyskusje. Znamienne w tym kontekście jest to, że Woland w powieści Bułhakowa to obraz nieporównanie potężniejszy i wyraźnie przesłaniający figurę Jeszui i Mistrza. Symptomatyczne są iluzoryczność i sztuczność (niewiarygodne zbiegi okoliczności, spotkania) „realistycznego” planu powieści Pasternaka, które są kompensowane poetycką logiką Wierszy Jurija Żywago, a także konflikt między deklarowaną przez autora i bliskich jemu bohaterów potrzebą „,połączenia się z narodom” a inteligenckim posłannictwem, zabarwionym cechami ofiarnego losu.

Co więcej, intensyfikacja nieregularności i przesunięcia znaczeniowego powtarzanych elementów aktywizuje przeciwny, odśrodkowy wektor metaprozatorskiej konstrukcji.W powieściach Konstantina Waginowa,Znaczku Egipskim [Эгипетская марка] Osipa Mandelsztama, Przypadkach [Случаяx] Daniiła Charmsa i Lolicie [Лолита] Władimira Nabokowa ,śmierć autora” albo zagłada kultury, albo klęska projektu modernistycznego całkowicie poddają się tematyzacji.U Mandelsztama i Waginowa stworzenie twórcy indywidualnych mitów jest nieodłączne od historycznej katastrofy i od rozpadu ciągłości uniwersum kulturowego, spowodowanych przez rewolucję. A w tekstach 
Charmsa, tak jak i w Lolicie [Лолита] Nabokowa, subiektywna aktywność twórcza nie tylko nie przeciwstawia się chaosowi, ale i zwielokrotnia chaotyczność świata. To ostatnie prowadzi do radykalnego przedefiniowania możliwości kultury w ogóle i stwarza intelektualne i symboliczne porządki ponad potwornościami historii i chaosem codzienności.

\section{II}

Awangarda podziela wszystkie nazwane cechy modernistycznej artystyczności, jednak proponuje ich zradykalizowaną wersję. Jak twierdził Maksim Szapir: ,Rzecz w tym, że w sztuce awangardowej pragmatyka wychodzi na pierwszy plan. Najważniejsze staje się działanie sztuki - jej celem jest zaszokowanie, rozbudzenie, poruszenie, spowodowanie aktywnej reakcji człowieka, który dotąd stał z boku"27. Utwór awangardowy zawsze zakłada przekroczenie granicy oddzielającej świat artystyczny od pozaestetycznego oraz bezpośrednie, szokowe wtargnięcie w nieświadomość czytelnika/widza. Tymczasem rozumienie sztuki jako „maszyny nieświadomości”28 albo jako narzędzia do bezpośredniego oddziaływania na nieświadomość (teoria Siergieja Eisensteina) w istocie różni się od wyobrażenia nieświadomości typowego dla modernizmu: maszyna zakłada aktywne działanie, a obiektem tego działania - raczej magicznego niż racjonalnego - jest czytelnik/widz, czyli w szerszym znaczeniu pozatekstowa realność. W uproszczeniu można powiedzieć, że modernizm jest kontemplatywny w porównaniu z awangardowym aktywizmem, modernizm jest głębszy, za to awangarda bardziej wyrazista. Modernizm nie zrywa z istniejącymi językami kultury, natomiast awangarda dąży do stworzenia nowych języków. Chociaż oczywiście nie należy zapominać o tym, że zarówno modernizm, jak i awangarda przynależą do jednego, wspólnego, nieklasycznego paradygmatu artystyczności i wielu autorów lat 20. i 30. XX wieku wielokrotnie przekraczało zupełnie umowną granicę między awangardą a modernizmem.

27 S. Szapir Czym jest awangarda?, przeł. P. Fast, w: M. Szapir Doświadczenia estetyczne XX wieku: awangarda i postmodernizm, „ER(R)GO. Teoria-Literatura-Kultura” $2015 \mathrm{nr} 2$ (31), s. 108.

B. Groys pisał: „Maszyny rosyjskiej awangardy były jednak w rzeczywistości maszynami podświadomości [powinno być nieświadomości przyp. tłum. A.Ś.], pragnień, miały charakter magiczny. Ich zadaniem było oporządzenie podświadomości [nieświadomości przyp. tłum. A.Ś.] artysty i widza, ażeby poprzez zjednoczenie ich z kosmiczną całością nadać im harmonię i zarazem uratować". B. Groys Stalin jako totalne dzieło sztuki, przeł. P. Kozak, Sic!, Warszawa 2010, s. 156. 
Awangardowe przeakcentowanie modernistycznej mitotwórczości wiąże się przede wszystkim z innym niż w „klasycznym” modernizmie rozumieniem sacrum. W awangardzie mit zamieniany jest na utopię: awangarda ksztattuje nie „wiecznośc", a „nowy świat" - nowy język, nowa psychikę, nowego człowieka, nowa kulture, nowe społeczeństwo. Według słów Wiktora Szkłowskiego ostatnim projektem awangardowego formowania współczesności jest „,stworzenie nowego światoodczucia, przeniesienie i rozprzestrzenienie metod projektowania przedmiotów artystycznych na projektowanie «przedmiotów codziennego użytku». Ostatecznym celem takiego posunięcia powinno być skonstruowanie nowego, namacalnego świata"29.

Utopia nie jest jedynie mitem o przyszłym złotym wieku, charakteryzuje się funkcją projekcji, a ściślej mówiąc życiotworzenia. Innymi słowy, ,Rzeczywistość jest bowiem rozpatrywana jako tworzywo [...]. Stosownie do swej immanentnej logiki, program estetyczny staje się programem estetyczno-politycznym"30. Stąd związek sztuki awangardowej z ekstremistycznymi ideologiami, a przede wszystkim z bolszewizmem.

Właśnie w polityce rewolucyjnej wielu rosyjskich awangardzistów ujrzało bezpośrednie ucieleśnienie swoich indywidualnych utopii i to dlatego tak aktywnie uczestniczyło w stworzeniu ,,nowego języka”, ,nowego człowieka” i „,nowych warunków życia” w latach 20. Można twierdzić, że „estetyzacja polityki",którą niemiecki filozofWalter Benjamin uważał za najbardziej niebezpieczną tendencję XX wieku, jest bezpośrednim wyrażeniem awangardy, tym bardziej że estetyzacji poddają się najbardziej radykalne ideologie polityczne. W przestrzeni literackiej oczywiście najbardziej jaskrawy przykład takiej utopii odnajdujemy w późnej twórczości Majakowskiego ${ }^{31}$, w szczególności w takich tekstach, jak: 150.000.000 [150.000.00o], Dobrze! [Xopomo!], Wtodzimierz Iljicz Lепіn [Владимир Ильич Ленин], później kanonizowanych przez socrealizm. Pod koniec lat 20. dochodzi skądinąd do próby stworzenia awangardy poza sferą wpływów utopii i poza polityką (mowa tu o OBERIU), ale w atmosferze narastającej ideologicznej monopolizacji ta „,inwersja” również nabiera radykalnego politycznego znaczenia, chociaż i późniejsza ewolucja oberiutów, a przede wszystkim Charmsa i Wwiedienskiego, świadczy o ich podążaniu od awangardy ku modernizmowi, a właściwie ku surrealizmowi

В. Шкловский Ход коня: Книга статей, Геликон, Москва 1923, s. 106.

B. Groys Stalin, s. 36-37.

31

Światopogląd Majakowskiego od strony religijno-mitologicznej przekonująco został przeanalizowany w: М. Вайскопф Во весь логос: религия Маяковского, НЛО, Москва 2003. 
(w zachodniej sztuce zajmującemu środkową pozycję między modernizmem a awangardą).

Zamiana mitotwórczości na stworzenie utopii nie mogła nie wywrzeć wpływu na taką strukturotwórczą zasadę modernistycznego paradygmatu artystyczności jak subiektywizm, a raczej subiektywny relatywizm. Jeśli przed rewolucją awangardowe utopie nowej wizji i nowej świadomości miały jeszcze silnie indywidualny charakter, co wzmagało efekt szokowy awangardowych gestów, to po rewolucji powstała iluzja możliwości produkowania uniwersalnych, a - co najważniejsze - politycznie pożądanych utopijnych modelów. W tej atmosferze subiektywny charakter mitotwórczości, a właściwie utopijnej twórczości, jest celowo redukowany albo maskowany: anonimowe prace artystów szkoły suprematycznej Unowis (wśród których założyciel szkoły Kazimierz Malewicz); uczniowie Michaiła Matiuszyna, którzy przyjęli jedno wspólne dla wszystkich nazwisko Ender; produkcjonizm, konstruktywizm i praca awangardzistów w dziedzinie reklamy i w politycznej agitacji; walka członków ugrupowania LEF „przeciwko indywidualistycznej literaturze pięknej za literaturę praktyczną, prasową" (Osip Brik) ${ }^{32}$, towarzyszącej formowaniu ,literatury faktu" - wszystkie te fenomeny (i wiele podobnych) świadczyły o celowej redukcji subiektywizmu w awangardzie. Ta tendencja logicznie prowadziła do socrealizmu i do przeobrażenia pisarza-awangardzisty w rzecznika państwowej, tzn. uniwersalnej utopii. Jak słusznie zauważa Boris Groys, „[...] granice budującego życie projektu totalnej mobilizacji w imię pięknej formy leżą w militarno-politycznej władzy, która nie tyle projektuje ową mobilizację, co wprowadza ją w czyn"33.

Jednak, jak pokazuje historia, tylko nieliczni artyści awangardowego kierunku byli w stanie wpisać się w kulturę socrealistyczną - większość padła ofiarą kulturalnych i politycznych represji. Rzecz najprawdopodobniej w tym, że niezależnie od chęci twórców sztuki awangardowej tworzone przez nich utopie nowej świadomości, nowego człowieka, nowej wizji i nowego bytu zachowują, a nawet wyostrzają - dzięki radykalizmowi awangardowej formy - pryncypialnie ambiwalentny charakter sakralności, typowy dla modernistycznego paradygmatu w ogóle. Nawet w Pluskwie [Kлon] Majakowskiego utopię komunistycznej przyszłości jednocześnie odczytuje się jako antyutopię, przypominającą $M y[M b l]$ Zamiatina. A montaże i fotografie

32 Литература факта: Первый сборник материалов работников ЛЕФа, ред. Н.Ф. Чужак [Переиздание 1929 года], Захаров, Москва 2000, s. 285. 
Aleksandra Rodczenki, powołane do udokumentowania nowego człowieka, jednocześnie utrwalają przerażające rysy wyłaniającej się monstrualności, jeszcze pogłębianej mechaniczną symetrią póz i gestów.Ta ambiwalentność, dwuznaczność awangardowego utopizmu, lekko łącząca utopię z antyutopią, w rezultacie stanie się najważniejszym chwytem poetyki Andrieja Płatonowa. Ale właśnie niejednoznaczność sakralizacji, nieprzezwyciężone dążenie do problematyzacji stwarzanej utopii czyniły awangardową estetykę sprzeczną z potrzebami kultury totalitarnej. Właśnie ta dogłębna właściwość awangardowej estetyki jest odpowiedzialna za tragiczne losy nawet najbardziej lojalnych wobec nowej ideologii awangardzistów (wachlarz od Władimira Majakowskiego i Wsiewołoda Meyerholda po Siergieja Trietiakowa i Siergieja Eisensteina).

Zupełnie oczywiste związki i/lub nieświadome nawiązania tych czy innych autorów lat 20. i 30. XX wieku z takimi „srebrnowiekowymi” nurtami, jak z jednej strony neoromantyzm, symbolizm, akmeizm czy futuryzm, a z drugiej współczesne im, zachodnie wersje ekspresjonizmu, surrealizmu, dadaizmu, neoklasycyzmu, nie powinny przesłaniać przynajmniej dwóch ważnych czynników rozwoju modernizmu i awangardy zarówno w literaturze sowieckiej, jak i w literaturze rosyjskiej emigracji.

Po pierwsze bowiem, rozmaite modernistyczne dyskursy, które przeszły już okres formowania i rozgraniczenia (inaczej nazywany srebrnym wiekiem), po rewolucji stają się znacznie bardziej otwarte na dialogową interakcję ze sobą na tyle, że praktycznie nie sposób znaleźć wielkiego pisarza-modernisty, którego estetykę byłoby można jednoznacznie scharakteryzować zgodnie z kategoriami należącymi do jednego ze znanych modernistycznych czy awangardowych nurtów. Achmatowa w latach 20.-40.XX wieku przekracza granice akmeizmu, deklaracje oberiutów nie wyjaśniają całej złożoności twórczości Charmsa, a czytanie Nabokowa jako ostatniego symbolisty w istocie ubezpośrednia i prymitywizuje logikę jego ewolucji.

Po drugie, wszyscy moderniści i awangardziści lat 20. i 30. XX wieku byli połączeni wspólnym doświadczeniem olbrzymich historycznych katastrof: wojną światową, rewolucją, wojną ojczyźnianą, terrorem towarzyszącym rewolucyjnym kataklizmom i kontynuowanym z nową siłą państwowym formowaniem państwa totalitarnego, a następnie i nową wojną światową, postrzeganą przez wielu jako tragiczna klęska nowoczesności (modernosti). Te traumatyczne doświadczenia są nieporównywalne w swojej skali i historycznym znaczeniu ze wstrząsami epoki srebrnego, a nawet XIX wieku. Moderniści i awangardziści lat 20. i 30. XX wieku, mimo wszelkich różnic 
metod, poetyk i filozofii, byli połączeni wspólnym znaczonym (signifié) przeżywaniem upadku cywilizacji, doświadczeniem historycznego chaosu, zetknięciem się z przemocą jako czynnikiem historii i kultury, reakcjami na próby stworzenia społeczeństwa według nowego modelu na miejscu ruin tradycyjnej kultury. Zwrócenie się w stronę tego doświadczenia podwyższało znaczenie realistycznej tradycji, przeciw której właściwie był ukierunkowany estetyczny bunt modernizmu i awangardy w latach 1890-1900. W latach 1920-1930 arsenał rosyjskiej literatury realistycznej, poszukującej dogłębnych związków między jednostką a warunkami środowiska społeczno-kulturowego, cieszył się powodzeniem nawet wśród najbardziej zagorzałych awangardzistów. Jednak, zakładając radykalne odnowienie jego wewnętrznej struktury poprzez logikę modernistycznej lub awangardowej świadomości i nie oznaczając zwykłego ",powrotu” do realizmu, nawet w tych przypadkach, kiedy autor deklarował swoje oddanie temu ostatniemu (znaczące pod tym względem są przykłady Pasternaka albo Szałamowa ${ }^{34}$ ), interakcja z realistycznym dyskursem także nosiła dialogiczny charakter.

\section{Przełożyła Agnieszka Ścibior}

\section{Abstract}

\section{Mark Leiderman (Lipovetsky) \\ UNIVERSITY OF COLORADO (BOULDER, USA) \\ Modernism and Advance Guard: Cognation and Difference}

The author examines the relationship between modernism and the avant-garde as a theoretical problem. He draws on the work of Russian writers who were both influential in the 1920s and at the same time very diverse - Boris Pasternak, Marina Tsvetaeva, Vladimir Mayakovsky, Andrei Platonov - to identify unique aspects of their poetics as well as the points where they overlap in the face of traumatic historical events.

\section{Keywords}

Russian literature, modernism, avant-garde, silver age, poetics

34 Zob. dokładniej: Н.Л. Лейдерман Постреализм: Теоретический очерк, Уральский государственный педагогический университет, Екатеринбург 2005, s. 7-54, 120-174. 